\title{
NDP-055
}

\section{Tropical Africa: Land Use, Biomass, and Carbon Estimates for 1980}

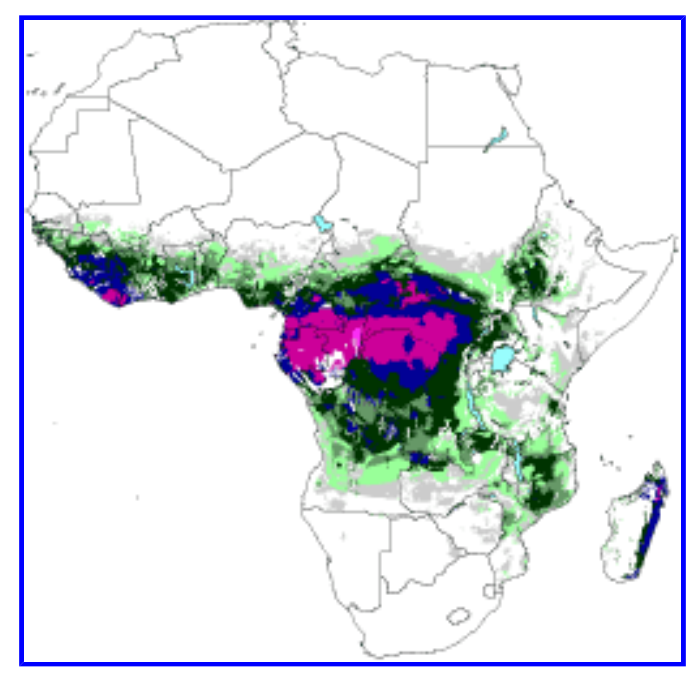

Contributed by

\author{
Sandra Brown ${ }^{1}$ \\ Greg Gaston ${ }^{2}$ \\ Work on this project was initiated while at the \\ Department of Natural Resources and Environmental Sciences \\ University of Illinois \\ Urbana, Illinois \\ 61801, U.S.A. \\ ${ }^{1}$ Present address: Winrock International, Arlington, Virgina. \\ ${ }^{2}$ Present address: Department of Geosciences, Oregon State University.
}

- Abstract

- Access data and ASCII documentation files

- The user may view and print a breakdown by country of the amount of land and biomass in open and closed forest in 1980, and the reclassification scheme used to obtain the four land use cateogries used in NDP055 using the free Adobe ${ }^{\circledR}$ Acrobat ${ }^{\circledR}$ Reader software.

- Users may also review an abstract representing pertinent literature.

Prepared by T.W. Beaty, and L.M. Olsen.

Carbon Dioxide Information Analysis Center

Environmental Sciences Division

Date Published: June, 1996 (Revised 2001) 
Prepared by the

Carbon Dioxide Information Analysis Center

OAK RIDGE NATIONAL LABORATORY

Oak Ridge, Tennessee 37831-6335

managed by

University of Tennessee-Battelle, LLC

for the

U.S. DEPARTMENT OF ENERGY

under contract DE-AC05-00OR22725

\section{CONTENTS}

\section{LIST OF TABLES}

ABBREVIATIONS

ABSTRACT

1. BACKGROUND INFORMATION

2. SOURCE AND SCOPE OF THE DATA

3. DATA MANIPULATION AND INTERPOLATION

4. MODELING BIOMASS

5. DESCRIPTION OF DATA PROCESSING ROUTINE

6. REFERENCES

7. HOW TO OBTAIN THE DATA AND DOCUMENTATION

8. LISTING OF FILES PROVIDED

9. DESCRIPTION OF THE DOCUMENTATION FILE

10. DESCRIPTION, FORMAT, AND PARTIAL LISTINGS OF THE DATA FILES

11. SAS AND FORTRAN CODES TO ACCESS THE DATA

APPENDIX A: BREAKDOWN BY COUNTRY OF THE AMOUNT OF LAND AND BIOMASS IN OPEN AND CLOSED FOREST IN 1980

APPENDIX B: REPRINT OF PERTINENT LITERATURE

APPENDIX C: RECLASSIFICATION SCHEME USED TO OBTAIN THE FOUR LAND USE CATEGORIES USED IN THIS NDP 


\title{
LIST OF TABLES
}

1. Files in this numeric data package

2. Assignment of the biomass indices to potential biomass densities based on forest inventories

3. Emission of $\mathrm{CO}_{2}, \mathrm{CO}$, and $\mathrm{CH}_{4}$ that would have occurred if the measured reduction in dry biomass (from potential to actual in 1980) were burned as fuelwood.

4. Variable formats for biomax.asc (biomax grid), lakes.asc (lakes grid) and land.asc (land grid)

5. Variable formats for pd80.asc (pd80 grid) and bio1980.asc (bio1980 grid)

6. Variable formats of $t$ afr.asc and $t$ afr.pat

7. Variable formats of africa.asc and africa.patsum 1980

\section{ABBREVIATIONS}

CDIAC $=$ Carbon Dioxide Information Analysis Center

$\mathrm{FTP}=$ file transfer protocol

NDP = numeric data package

$\mathrm{QA}=$ quality assurance

GCM = General Circulation Model

UNEP = United Nations' Environmental Program

FAO = United Nations' Food And Agriculture Organization

GIS = geographic information system

$\mathrm{PBD}=$ potential biomass density

ARC/INFO is a registered trademark of the Environmental Systems Research Institute, Inc., Redlands, CA 92372. SAS is a registered trademark of the SAS Institute, Inc., Cary, NC 27511-8000.

\begin{abstract}
Brown, S, and Greg Gaston. 1996. Tropical Africa: Land Use, Biomass, and Carbon Estimates for 1980. NDP-055, Carbon Dioxide Information Center, Oak Ridge National Laboratory, Oak Ridge, Tennessee.
\end{abstract}

This document describes the contents of a digital database containing maximum potential aboveground biomass, land use, and estimated biomass and carbon data for 1980. The biomass data and carbon estimates are associated with woody vegetation in Tropical Africa. These data were collected to reduce the uncertainty associated with estimating historical releases of carbon from land use change. Tropical Africa is defined here as encompassing $22.7 \times 10^{6} \mathrm{~km}^{2}$ of the earth's land surface and is comprised of countries that are located in tropical Africa (Angola, Botswana, Burundi, Cameroon, Cape Verde, Central African Republic, Chad, Congo, Benin, Equatorial Guinea, Ethiopia, Djibouti, Gabon, Gambia, Ghana, Guinea, Ivory Coast, Kenya, Liberia, Madagascar, Malawi, Mali, Mauritania, Mozambique, Namibia, Niger, Nigeria, Guinea-Bissau, Zimbabwe (Rhodesia), Rwanda, Senegal, Sierra Leone, Somalia, Sudan, Tanzania, Togo, Uganda, Burkina Faso (Upper Volta), Zaire, and Zambia).

The database was developed using the GRID module in the ARC/INFO ${ }^{\mathrm{TM}}$ geographic information system. Source data were obtained from the Food and Agriculture Organization (FAO), the U.S. National Geophysical Data Center, and a limited number of biomass-carbon density case studies. These data were used to derive the maximum potential and actual (ca. 1980) aboveground biomass values at regional and country levels. The land-use data provided were derived from a vegetation map originally produced for the FAO by the International Institute of Vegetation Mapping, Toulouse, France. 
Analyses conducted with this database found that $18 \%$ of Tropical Africa was classified as closed forest and $36 \%$ was classified as open forest in 1980. Forested lands contained over 138 x $10^{9} \mathrm{Mg}$ of aboveground live biomass, which is equivalent to $69 \times 10^{9} \mathrm{Mg}$ of carbon. Closed forests and open forests had mean aboveground biomass values of 209 $\mathrm{Mg} / \mathrm{ha}$ and $67 \mathrm{Mg} / \mathrm{ha}$, respectively, in 1980. These values are down from maximum potential aboveground live biomass values of $296 \mathrm{Mg} /$ ha for closed forest and $108 \mathrm{Mg} / \mathrm{ha}$ for open forest.

Keywords: Carbon release, climate change, deforestation, forestry, population.

NDP-055 includes the following data and documentation files:

- descriptive text file (ndp055.txt)

- ARC/INFO projection file (trop_africa.prj) with parameters for the ARC/INFO grids and coverages included in this NDP.

- ARC/INFO exported integer grid (biomax.e00) containing maximum potential biomass density data in $\mathrm{Mg} / \mathrm{ha}$.

- ASCII format of BIOMAX grid (biomax.asc)

- ARC/INFO exported integer grid (lakes.e00) containing the location of all non-seasonal lakes.

- ASCII format of LAKES grid(lakes.asc)

- ARC/INFO exported integer grid (land.e00) containing land-use information.

- ASCII format of LAND grid (land.asc)

- FORTRAN code (intgrid.for) to read and print the ASCII data files (biomax.asc, lakes.asc, and land.asc)

- SAS retrieval program (intgrid.sas) to read and print the ASCII data files biomax.asc, lakes.asc, and land.asc.

- ARC/INFO exported floating point grid (bio1980.e00) containing the calculated actual aboveground live biomass in open and closed forests for $1980 \mathrm{in} \mathrm{Mg} / \mathrm{ha}$.

- ASCII format of BIO1980 grid (bio1980.asc)

- ARC/INFO exported floating point grid (pd80.e00) containing population density data for 1980.

- ASCII format of PD80 grid (pd80.asc)

- FORTRAN code (realgrid.for) to read and print the ASCII files pd80.asc and bio1980.asc.

- SAS retrieval program (realgrid.sas) to read and print the ASCII datafiles pd80.asc and bio1980.asc.

- ARC/INFO exported coverage (africa.e00) containing the amount and biomass in open and closed forest by country.

- ARC/INFO exported coverage (t afr.e00) containing population data for 1960, 1970, 1980 and 1990 for the subnational political units used in this NDP.

- ASCII file (africa.asc) containing the attribute information associated with africa.e00.

- FORTRAN code (africa.for) to read and print africa.asc.

- SAS retrieval program (africa.sas) to read and print africa.asc.

- ASCII file (t_afr.asc) containing the attribute information associated with t_afr.e00.

- FORTRAN code (t afr.for) to read and print t_afr.asc.

- SAS retreival program (t_afr.sas) to read and print t_afr.asc.

- Graphic Map, "Maximum Potential Biomass Density" (africa_biomax.gif)

- Graphic Map, "Land use" (africa_lc.gif")

- Graphic Map, "Area of Closed Forests (By Country)" (areaclsdforest.gif)

- Graphic Map, "Area of Open Forests (By Country)" (areaopnforest.gif)

- Graphic Map, "Mean Biomass of Closed Forests (By Country)" (clsdforestbio.gif)

- Graphic Map, "Mean Biomass of Open Forests (By Country)" (opnforestbio.gif)

- Graphic Map, "Percent Forest Cover (By Country)" (pctforest.gif)

- Graphic Map, "Total Forest Biomass (By Country)" (totforestbio.gif)

- Graphic Map, "Population Density - 1990" (pop1990.gif)

- Graphic Map, "Population Density - 1980" (pop1980.gif)

- Graphic Map, "Population Density - 1970" (pop1970.gif) 
- Graphic Map, "Population Density - 1960" (pop1960.gif)

- text file of data tables (table.txt)

\section{BACKGROUND INFORMATION}

This database was developed by Sandra Brown, Louis Iverson, Ariel Lugo, Anantha Prasad, Greg Gaston, and others between 1990 and 1994. The primary contract that supported the collection of the data was the U.S. Department of Energy, Office of Health and Environmental Research, contract DEFG02-90ER61081. Additional support was obtained from the U.S. Environmental Protection Agency through its post doctoral fellowship program, which is administered by the National Research Council.

Human-induced changes in the Earth's land cover may influence ecological and climatic systems. The potential for these changes to have regional or global implications makes the task of developing an all-inclusive general circulation model (GCM) with predictive capabilities essential. However, to accurately predict the effects of long-term increases in the number and concentration of greenhouse gases on climate, GCMs require information on the timing and magnitude of past releases of $\mathrm{CO}_{2}$, methane, nitrous oxide, water vapor, and a host of other anthropogenic gases. An understanding of all of the major processes leading to the release (sources) and storage (sinks) of these gases over time is also essential.

The prediction of regional trends in climate will be problematic until a well- documented understanding of the past, present, and possible future usage of fossil fuels and land is reached. Such an understanding is possible only with the concerted effort of many investigators from a diverse set of disciplines. The perspectives of ecologists, biologists, historians, geographers, foresters, mathematicians, physicists, and others are needed if a multifaceted examination of the causes and consequences of land-cover change and human population growth on the world's climate is to be conducted.

Reductions in the amount of carbon stored in terrestrial ecosystems are partially responsible for the increase in the concentration of atmospheric $\mathrm{CO}_{2}$ that has occurred since 1850 (Houghton 1993). For example, live vegetation in terrestrial ecosystems is estimated to have contained over $900 \mathrm{Pg}$ of carbon, with $90 \%$ of this being in forests, prior to any intentional land clearing on Earth (Olson et al. 1985, Dale et al. 1991).

A decline in the amount of carbon sequestered in vegetation has been associated with the rapid increase of human population that began during the industrial revolution. This population growth created demands for food and forest products that were fulfilled through the clearing and conversion of large tracts of forest to agriculture and other uses. This land-cover change has direct impacts on the concentration of atmospheric $\mathrm{CO}_{2}$. For example, a $1 \%$ change in the total amount of carbon stored in living vegetation would release about $21 \mathrm{Pg}$ of carbon to the atmosphere, almost four times the present annual emission from fossil fuels (Houghton 1993).

\section{SOURCE AND SCOPE OF THE DATA}

This numeric data package (NDP-055) describes a land-use and biomass database for Tropical Africa that contains 1980 land cover, maximum potential aboveground biomass, and biomass estimates for woody vegetation in 1980. In addition, the database includes information on human populations in each nation and sub-national political unit in Tropical Africa for the years 1960, 1970, 1980, and 1990. These data were collected to reduce the uncertainty associated with the possible magnitude and time course of historical releases of carbon from land-cover change and may be used by demographers, historians, geographers, and other researchers interested in the relationship between land cover change, land degradation, climate, and anthropogenic activities. 
For purposes of this NDP, Tropical Africa is defined as encompassing nearly $22.7 \times 10^{6} \mathrm{~km}^{2}$ of the world's surface and includes the following countries: Angola, Botswana, Burundi, Cameroon, Cape Verde, Central African Republic, Chad, Congo, Benin, Equatorial Guinea, Ethiopia, Djibouti, Gabon, Gambia, Ghana, Guinea, Ivory Coast, Kenya, Liberia, Madagascar, Malawi, Mali, Mauritania, Mozambique, Namibia, Niger, Nigeria, Guinea-Bissau, Zimbabwe (Rhodesia), Rwanda, Senegal, Sierra Leone, Somalia, Sudan, Tanzania, Togo, Uganda, Burkina Faso (Upper Volta), Zaire, and Zambia. As defined here Tropical Africa does not include countries in Mediterranean and southern Africa (i.e., Egypt, Libya, Tunisia, Algeria, Morocco, Western Sahara, South Africa, Lesotho, and Swaziland).

The major effort in the compilation of this database involved the acquisition and processing of the source data sets. Most of these data sets were acquired from the United Nations Environmental Program's (UNEP) Global Resources Information Database (Jaakkola 1990) or from the United Nation's Food and Agriculture Organization (FAO 1993). These data, in turn, were input, georeferenced, and converted into a raster format as needed using an $\mathrm{ARC} / \mathrm{INFO}{ }^{\mathrm{TM}}$ geographic information system (GIS). The spatial data sets used in the development of this NDP are as follows:

1. National boundaries were derived from the U.S. Defense Mapping Agency's Digital Chart of the World at a scale of 1:1,000,000. Boundaries for subnational political units were derived from The New International Atlas, the Encyclopedia of the Nations, and the FAO's Tropical Forest Resources Assessment Program 1990 population data (Worldmark Press 1984, Rand McNally 1980). Boundaries for large water bodies (e.g. Lake Victoria) were copied from the Digital Chart of the World; moderate sized lakes ( $>20 \mathrm{~km}$ in length in any direction) were digitized from the UNESCO Vegetation Map of Africa, scale 1:5,000,000 (UNESCO/AETFAT/UNSO 1981, White 1983).

2. Population density data for 1960, 1970, 1980, and 1990 for national and subnational political units were provided by M. Lorenzini and K.D. Singh, FAO, Tropical Forest Resources Assessment Program 1990 (FAO 1993).

3. Elevation data were derived from a global digital elevation database originally developed by the U.S. Defense Mapping Agency (ETOPO5). The elevation data were reclassified into 15-m increments, and all bathymetry data were set to zero.

4. Soils data were derived from the FAO Soils Map of the World (FAO 1971-81). The soils data were reclassified into five soil texture classes, five slope classes, and two soil depth classes and were used in calculating the maximum potential biomass values included with this database. These soil data are not included with this NDP.

5. Climatic data were obtained from the FAO agro-meteorology database and two maps were developed using the spatial coordinates for each station and the mean monthly precipitation, maximum temperature, minimum temperature, day-night temperature differential, evapotranspiration rate, and vapor pressure. The first map is a isopleth map of annual precipitation and the second is of an integrated climate index that provides a measure of the growing season length based on five climatic variables (Weck 1970).

6. Vegetation data represent conditions in 1980 (approximate date) from the FAO Vegetation Map of Africa (Lavenu 1987).

\section{DATA MANIPULATION AND INTERPOLATION}

The methodology described in Iverson et al. (1994) and Brown and Gaston (1995) (Abstract) was used to compute degradation ratios. These degradation ratios were applied to a map of maximum potential aboveground biomass density to develop a map of current (ca. 1980) aboveground biomass. Since the linear regression models used to estimate the degradation ratios were calibrated for woody vegetation only, this map was masked using a land cover map (1980). All 
areas not in a forested or wooded class were deleted. This process resulted in a map showing the amount of aboveground biomass in woody vegetation for 1980. The change (emission) of carbon resulting from land use change and land degradation between the 1880 s and 1980 can be estimated for closed and open forests by comparing the aboveground biomass map with the maximum potential aboveground biomass density map.

Two of the data sources used in calculating the maximum potential aboveground biomass values needed additional processing before they could be used in the biomass estimation model. First, the meteorology data were used to calculate a climatological index for each station based on a modified version of Weck's (1970) methodology. Second, these climatological indices (point data) were interpolated into a thematic map using a thin-plate spline technique (Iverson et al. 1994). Lastly, the FAO vegetation map used (Lavenu 1987) was reclassified from over 64 ecosystem types into a map showing closed forest, open forest, grassland savanna, and other non-forested lands. See Appendix C for a description of the reclassification scheme used.

The source data were then projected into a cylindrical equal-area projection using a central meridian of $15^{\circ}$ East and a standard parallel of $0^{\circ}$. The data were then converted into grids (cellsize $5 \mathrm{~km}$ ) using the ARC/INFO TM POLYGRID command.

\section{MODELING BIOMASS}

The maximum potential biomass density of woody vegetation is assumed to be the product of a combination of the prevailing climatic and geomorphic conditions in an area. To estimate the maximum potential biomass for each grid cell, each input layer (i.e., mean annual precipitation, climate index, elevation/slope, and soil quality/texture) was recoded and assigned values ranging from 1 to 25 based on the perceived importance of the layer to the growth of woody vegetation. A weighted overlay of the four layers was then performed to create a biomass index with a minimum possible value of 4 and a maximum value of 100 (in Tropical Africa the values ranged from 40 to 100).

The climate-related layers (mean annual precipitation and climate index) account for 50\% of the possible index value. The soil layer accounts for $25 \%$ and the elevation and slope layer [formed by combining the elevation data (maximum value 13) with the slope data (maximum value 12)] accounts for the remaining 25\%. Iverson et al. (1994) used the same weighting scheme for Tropical Asia. This scheme was found to give satisfactory results for Africa when compared to available literature for the region (Graham et al. 1990, Martin 1991, Lavenu 1987).

Potential biomass density (PBD) indices for forests, woodlands, and woody savannas were calibrated by assigning aboveground biomass density estimates (obtained from the literature) to the range of index values. This task posed a challenge because few measurements of mature forest biomass have been taken in this region (Brown and Lugo 1982). The highest reported biomass densities were about $500 \mathrm{Mg} /$ ha (Huttel and Bernhard-Reversat 1975, Huttel 1975) for tropical moist forests in western Africa. Western Africa is also associated with the highest range of PBD indices (>96). A PBD index value of 51 was assumed to represent the lower limit for tree or shrub savannas and was assigned a biomass density of $15 \mathrm{Mg} /$ ha based on data in Lamotte (1975), Lamotte and Bourliere (1983), and Menaut et al. (1991). It was then assumed that biomass density exhibited a logistic-shaped function between the PBD index and biomass. Biomass values (in $\mathrm{Mg} / \mathrm{ha}$ ) were assigned to the PBD values as shown in Table 2. The lower index value (i.e., 40) and upper index value (i.e., 100) for Tropical Africa were equated with $1 \mathrm{Mg} / \mathrm{ha}$ and with $500 \mathrm{Mg} / \mathrm{ha}$, respectively. Between these two bounds the potential biomass index was divided into twelve ranges. Intermediate values of biomass density were obtained or estimated from Greenland and Kowal (1960), Pierlot (1966), Feson et al. (1974), and Brown et al. (1994).

The remainder of this methodology is designed for woody vegetation only. Thus, the next step in determining the biomass in forests for 1980 was to remove non-woody vegetation associations from the map of maximum potential biomass density that is distributed with this database. This was done by taking the reclassified FAO vegetation map for 1980 (Lavenu 1987) [i.e., with four classes: closed forest, open forest (woodland/wooded savanna), grassland savanna, 
and other] and setting those grid cells with closed forest or open forest to a value of 1 . All other cells were set to NODATA. This temporary map was multiplied by the potential biomass density map. This process set or masked most grid cells that were not classified as woody vegetation (as of 1980) to NODATA. The resulting maximum potential biomass density map, therefore, is of forested areas only. The only non-wooded areas remaining in this map are grid cells located within lakes.

To estimate the actual biomass remaining in live woody vegetation in 1980, researchers developed degradation ratios based on population data and applied them to the maximum potential biomass density map for forested lands. The degradation ratios were based on the assumption that the degree to which forests are reduced from their potential biomass is a function of the population density and forest type or ecofloristic zone. For example, high population densities will result in low degradation ratios (i.e., highly degraded forests), and drier regions will be degraded more severely than moist regions because of the ability of moist forests to replace biomass faster (Brown and Lugo 1982).

Other socioeconomic factors such as the ratio of rural to urban population, the importance of subsistence versus exportoriented agriculture, and the state of industrialization affects the rate of biomass reduction. In developed countries a population density and a stage of industrial development have been reached at which no further biomass loss occurs and other factors come into play, which may actually lead to increases in biomass (Flint and Richards 1994).

In most of Tropical Africa this threshold has not been reached, as exemplified by the fact that $90 \%$ of the population in Africa still uses wood for cooking. The average amount of wood used for cooking per family is equivalent to about 1.5 tons of fuel oil per year. It has been estimated that the annual addition to the fuelwood supply through the growth of biomass was less than consumption in 1980 and that the half-life of tree stocks (the time it would take for stocks to decline by 50\%) averaged about 25 years in 1980. Furthermore, tree stocks are declining at accelerating rates because consumption is increasing exponentially with population growth (Anderson and Fishwick 1984).

Degradation equations have been estimated for two forest types (closed forest and woodland/wooded savanna) by comparing the potential biomass density in 1980 with biomass densities obtained from forest inventories for the same location. This process produced unitless factors that indicate the reduction from potential biomass to actual biomass as a function of population density. Eight reliable forest inventories for Tropical Africa were used to develop the degradation equations (Clement and Nouvellet 1978, Development and Resources Corporation 1967, Republique de Cote d'Ivoire 1975, United Nations 1972, FAO 1989). Due to the limited number of suitable forest inventories of tropical Africa, 27 additional inventories from tropical South and Southeast Asia were also included in the analysis (Iverson et al. 1994).

The data for the closed forest zone of Tropical Africa were combined with the moist forest data from South and Southeast Asia, while data for the woodland/wooded savanna zone were combined with the dry forest data from South and Southeast Asia. A least-squares regression was conducted for each zone, and the following degradation equations were produced.

The equations, sample sizes, and correlation results for closed forest are:

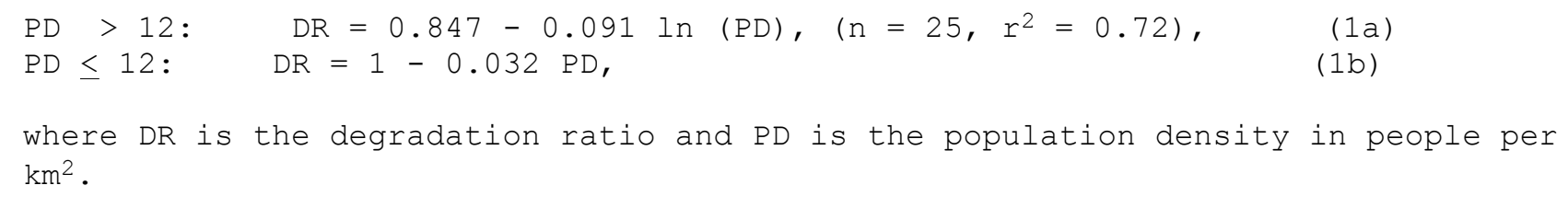

The equations, sample sizes, and correlation results for open forest (woodland/wooded savanna) are:
$\mathrm{PD}>7:$
$\mathrm{PD} \leq 7:$
$\mathrm{DR}=0.866-0.118 \mathrm{ln}$
$(\mathrm{PD})$
$\left(n=10, r^{2}=0.54\right)$,
(2a)
$\mathrm{DR}=1-0.050 \mathrm{PD}$,
(2b) 
where $\mathrm{DR}$ is the degradation ratio and $\mathrm{PD}$ is the population density in people per $\mathrm{km}^{2}$.

Equation 1a and 2a for each forest type is based on the range of available data, and the minimum PD for which it is applicable. For PDs less than these minimums, simple linear equations (Eq. $1 \mathrm{~b}$ and $2 \mathrm{~b}$ ) were developed between the DR at zero PD (assumed to be one), and the value of DR from equation 1a and $2 \mathrm{a}$ at the minimum PD. A linear function of PD was then calculated for each land cover class between these DR values.

Use of the natural logarithm in equations 1a and 2a allows negative DR values to occur for PDs greater than 11,022 for closed forest and 1,539 for the open forest (woodland/wooded savanna) land cover classes. This was not a problem in most cases, however, since forest lands tend to have lower population densities. For this reason, calculated DR values less than 0.1 were reset to 0.1 .

The actual-biomass-density map for 1980 is the product of the potential-biomass- density map for woody vegetation, the population density map for 1980 stratified by land cover type (closed forest and open forest), and the calculated degradation ratios. The map of actual biomass densities for 1980 was calculated on a cell-by-cell basis. All cells within a political unit were assigned the same population density value. The forest strata, however, may vary within a political unit causing the degradation equation used to vary. Thus, the map of actual biomass density for woody vegetation in 1980 reflects the predicted maximum potential biomass, the forest type stratification, and the population density in 1980.

Due to the coarse scale of the input data used in generating the potential biomass density map, some large water bodies within Africa were not represented. Boundaries for large water bodies (e.g., Lake Victoria) and moderate sized lakes $(>20 \mathrm{~km}$ in length in any direction) were digitized and entered into a lake coverage (map). Following a process similar to that used for the land cover data, those grid cells within a lake (i.e., $>50 \%$ ) were given a value of NODATA, and the remainder were set to one. This coverage was multiplied by the grid cells in the map of actual biomass density for 1980 to set all "wet" grid cells to NODATA.

This final map of actual live aboveground biomass density only contains lands that were in closed forest (moist forest and seasonal forest) or open forest (woodland/wooded savanna) in 1980 (per Lavenu 1987). The final map contains $4,025,275 \mathrm{~km}^{2}$ of closed forest land with a mean biomass density of $208.7 \mathrm{Mg} / \mathrm{ha}$ and $8,156,575 \mathrm{~km}^{2}$ of open forest land (woodland/ wooded savanna) with a mean biomass density of $67.1 \mathrm{Mg} / \mathrm{ha}$. As expected, the minimum biomass densities were located in lowland dry zones to the north and south, maximum values were located in the humid lowlands in southwest and south central Africa (i.e., Congo, Gabon, Zaire), and highland areas had slightly less biomass than their lowland counterparts. The presence of these known patterns increased our confidence in this methodology and its ability to generate reasonable estimates of biomass density for Tropical Africa.

The primary product of this GIS methodology is the actual biomass density information for woody vegetation in 1980 . Actual biomass density in year X may be determined (as described for 1980) using a land-cover map and population data for year X (e.g., 1990). The results may then be compared to determine the change in biomass (carbon) of woody vegetation in the intervening years.

The biomass for 1980 may also be compared to the maximum potential aboveground biomass for the region. The difference between the mean maximum potential biomass density for closed forest lands and the mean actual biomass density in 1980 is $86.9 \mathrm{Mg} / \mathrm{ha}(40.5 \mathrm{Mg} /$ ha for open forest). On the basis of the average biomass to carbon conversion factor of $1 \mathrm{~kg}$ of wood to $0.5 \mathrm{~kg}$ of carbon (Smith 1991), and the assumption that the removed wood was eventually burned, the amount of $\mathrm{CO}_{2}, \mathrm{CO}, \mathrm{CH}_{4}$, and other gases emitted from this per ha reduction in biomass may be estimated for closed and open forests. Table 3 shows the estimated emission of $\mathrm{CO}_{2}, \mathrm{CO}$, and $\mathrm{CH}_{4}$ that would have occurred if 
86.9 (40.5) Mg of dry biomass were burned using traditional West African stoves, based on emission factors calculated by Brocard et al. (1995). (If forest fire based emission factors were used the emission of $\mathrm{CO}_{2}$ and $\mathrm{CO}$ would increase while the amount of $\mathrm{CH}_{4}$ and carbon in the "other" category would decrease.)

Africa had an estimated total population of 100 million people in 1650 (density of 0.03 people per $\mathrm{km}^{2}$ ). Two hundred years later (1850) the population was still around 100 million (Udo 1982). Thus, it may be assumed that prior to the colonial period, which began in the mid to late 1800s, the amount of land in forests had remained relatively stable for over two hundred years. Since the land in the closed forest and open forest (woodland/wooded savanna) land-cover classes in 1980 were located in the interior of larger forests in 1880, it can be assumed that they were at or near their maximum potential biomass density at the beginning of the colonial period. If this was the case, the emission of $\mathrm{CO}_{2}$ due to the degradation of these forested lands (i.e., reduction of biomass from the maximum potential to the "actual" biomass in 1980) would total $27.21 \times 10^{12} \mathrm{~kg} / \mathrm{C}$. If this $\mathrm{CO}_{2}$ had been emitted at a constant rate since $1880,272.1 \times 10$

${ }^{6} \mathrm{Mg} \mathrm{C}$ per year would have been released into the atmosphere. To put this figure into perspective, Houghton and Hackler (1995) calculated that the regional net flux of carbon in Tropical Africa from all land-use changes was 238.69 x $10^{6} \mathrm{Mg} \mathrm{C}$ in 1980 and had increased to $341.5 \times 10^{6} \mathrm{Mg} \mathrm{C}$ by 1990.

\section{LIMITATIONS AND RESTRICTIONS OF THE DATA}

The following paragraphs list the limitations and caveats that should be considered when using this database. Failure to consider these limitations could result in erroneous interpretations of the data.

1. All data coverages (maps) in this database have been resampled into $5 \times 5 \mathrm{~km}$ grid cells. This cell size and the small cartographic scale of most of the input data used preclude the use of these data for site-specific studies.

2. The soil texture, slope, and elevation data used in the development of the map of maximum potential aboveground biomass densities were based on small-scale data sources $(1: 1,000,000$ to 1:5,000,000).

3. The climate data were extrapolated into areas with little or no data. Consequently, effects of local topography on precipitation and temperature patterns are not considered in the map of maximum potential aboveground biomass.

4. The population data used to calculate the degradation ratios are based on national internal political subdivisions as of 1980. The population data provided with this database (i.e., for 1960, 1970, 1980, and 1990) are keyed to these 1980 divisions.

5. The limited number of forest inventories in Tropical Africa makes verification of the final map of actual biomass density for woody vegetation in 1980 difficult. However, average biomass densities were obtained for Guinea, Gambia, Mozambique, and Burkina Faso from national level forest inventories and compared to those calculated here. The values for Guinea, Gambia, Mozambique, and Burkina Faso were within 3\%, 19\%, 3\%, and 38\%, respectively, of the inventory values (Brown and Gaston 1995).

\section{DATA CHECKS PERFORMED BY CDIAC}

An important part of the data packaging process at the Carbon Dioxide Information Analysis Center (CDIAC) is the quality assurance (QA) of the data before its distribution. The QA process is an important component of the valueadded concept of ensuring accurate, usable information. The complete QA of a data set can be a time- consuming process, since data received by CDIAC are rarely in condition for immediate distribution, regardless of source. The following summarizes the QA checks performed on the various data groups presented in this document. 
1. The map of maximum potential aboveground biomass density is derived from an index calculated from six climatic and geomorphic variables. The index values were associated with the known upper and lower limits of biomass density in Africa, and the range was divided into 12 density groupings (Table 2). The maximum potential aboveground biomass density map ( $5 \times 5 \mathrm{~km}$ grid cells) was correlated with a 1x1 degree map of carbon in live vegetation (Olson et al. 1983). The analysis obtained an $\mathrm{r}^{2}$ value of $0.4, \mathrm{n}=1195611$, and $\alpha=0.0001$. Because of cell size differences, a higher correlation value should not be expected; however, the significance of the correlation (>99\%) implies that the two independently derived data sources are measures of the same variable.

2. The map of maximum potential aboveground biomass ( $5 \times 5 \mathrm{~km}$ grid cells) and the Olson et al. (1983) $1 \times 1$ degree map of carbon in live vegetation were printed and visually compared to ensure that the location of low and high carbon/biomass densities matched.

3. The land-use map for 1980 derived from Lavenu (1987) was printed and compared to a similar map prepared by the United Nations (White 1983).

4. On the basis of QA steps 2 and 3, it was determined that neither the land cover nor potential-biomass-density map had accounted for internal water bodies in Tropical Africa. A new map was created for use with this database that contains all permanent (versus seasonal) lakes larger than $20 \mathrm{~km}$ in length in any direction.

5. The population data for 1960,1970,1980, and 1990, were aggregated by country and compared to secondary data sources (e.g., WorldMark Press 1984, Udo 1982, and Goode 1992).

6. The final actual-biomass-density map for 1980 was aggregated on a cell-by-cell basis to obtain the mean biomass density by country (see

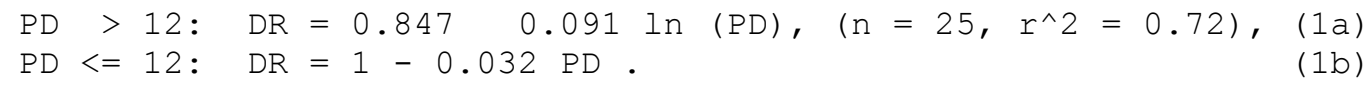

The equations, sample size, and correlation coefficient for open forest (woodland/wooded savanna) are:

$\mathrm{PD} \quad>7: \quad \mathrm{DR}=0.8660 .118 \ln (\mathrm{PD}), \quad\left(\mathrm{n}=10, \mathrm{r}^{\wedge} 2=0.54\right),(2 \mathrm{a})$

$\mathrm{PD}<=7: \quad \mathrm{DR}=1-0.050 \mathrm{PD}$.

Where DR is the degradation ratio and PD is the population density in people per $\mathrm{km}^{2}$.

\section{REFERENCES}

Anderson, D. and R. Fishwick. 1984. Fuelwood Consupmtion and Deforestation in African Countries. World Bank Staff Working Papers No. 704. The World Bank, Washington, D.C.

Brocard, D., C. Lacaux, J.P. Lacaux, G. Kouadio, V. Yoboue, M. Assa Achy, B. Ahoua, and M. Koffi. 1995. Emissions from the combustion of biofuels in the African tropics. In Biomass Burning and Global Change, J.S. Levine (ed.). MIT Press, Cambridge, MA.

Brown, S., Gaston G., and R. Daniels. 1996. Tropical Africa: Land Use, Biomass, and Carbon Estimates for 1980. ORNL/CDIAC-92, NDP-055. Carbon Dioxide Information Analysis Center, Oak Ridge National Laboratory, Oak Ridge, Tennessee.

Brown, S. and G. Gaston. 1995. Use of forest inventories and geographic information systems to estimate biomass density of tropical forests: Application to Tropical Africa. Environmental Monitoring 38: 157-168. 
Brown, S. and A.E. Lugo. 1982. The storage and production of organic matter in tropical forests and their role in the global carbon cycle. Biotropica 14: 161-187.

Brown, S., L.R. Iverson, A. Prasad, and D. Liu. 1993. Geographical distributions of carbon in biomass and soils of tropical Asian forests. Geocarto International 4: 45-59.

Clement, J. and Y. Nouvellet. 1978. Inventaire Forestier dans la Zone d'Edenzork. Republique du Gabon, Soceite Gabonaise de cellulose, Centre Technique Forestier Tropical, Nogent-sur-Marne, France.

Dale, V.H., R.A. Houghton, and C.A.S. Hall. 1991. Estimating the effects of land-use change on global atmospheric $\mathrm{CO}_{2}$ concentrations. Canadian Journal of Forest Research 21: 87-90.

Development and Resources Corporation. 1967. Forestry Resources of the Southwest Region. Government of the Republic of the Ivory Coast, New York.

Food and Agriculture Organization (FAO). 1993. Forest Resources Assessment 1990: Tropical Countries. Forestry Paper 112, FAO, Rome, Italy.

FAO. 1989. Studies on the Volume and Yield of Tropical Forest Stands: 1. Dry forest Formations. Forestry Paper 51/1, FAO, Rome, Italy.

FAO. 1971-81. Soils Map of the World 1:5,000,000. FAO/UNESCO, Rome, Italy.

Flint, E.P. and J.F. Richards. 1994. Trends in carbon content of vegetation in South and Southeast Asia associated with changes in land use, pp. 201-300. In Effects of Land-Use Change on Atmospheric $\mathrm{CO}_{2}$ Concentrations: South and Southeast Asia as a Case Study, V.H. Dale (ed.). Springer-Verlag Inc., New York.

Freson, R., G. Goffinet, and F. Malaisse. 1974. Ecological effects of the regressive succession mhulu-miombosavannah in Upper-Shaba (Zaire), pp. 365-371.In Proceedings 1st International Congress of Ecology. The Hauge, The Netherlands.

Goode, J.P. 1992. Goode's World Atlas. 18th Edition, Rand McNally, Chicago, Illinois.

Graham, R.L., R.D. Perlack, A. Prasad, J.W. Ranney, and D.B. Waddle. 1990. Greenhouse Gas Emissions in Sub-Saharan Africa. ORNL-6640. Oak Ridge National Laboratory, Oak Ridge, Tennessee.

Greenland, D.J. and J.M.L. Kowal. 1960. Nutrient content of the moist tropical forest of Ghana. Plant and Soil 12: $154-173$.

Houghton, R.A. and J.L. Hackler. 1995. Continental Scale Estimates of the Biotic Carbon Flux from Land Cover Change: 1850 to 1980. ORNL/CDIAC-79, NDP-050. Carbon Dioxide Information Analysis Center, Oak Ridge National Laboratory, Oak Ridge, Tennessee.

Houghton, R.A. 1993. Changes in terrestrial carbon over the last 135 years, pp. 139-157. In The Global Carbon Cycle, M. Heimann (ed.). NATO ASI Series, Vol. I 15. Springer-Verlag Inc., New York.

Houghton, T.A., W.H. Schlesinger, S. Brown, and J.F. Richards. 1985. Carbon dioxide exchange between the atmosphere and terrestrial ecosystems, pp. 113-140. In Atmospheric Carbon Dioxide and the Global Carbon Cycle, J.R. Trabalka (ed.). DOE/ER-0239. U.S. Department of Energy, Office of Energy Research, Washington, D.C. 
Huttel, C.H. 1975. Root distribution and biomass in three Ivory Coast rain forest plots, pp. 123-130. In Tropical Ecological Systems, F.B. Golley and E. Medina (eds). Springer Verlag Inc., New York.

Huttel, C.H., and F. Bernhard-Reversat. 1975. Recherches sur l'ecosysteme de la foret subequatoriale de base Cote D'Ivoire. Cycle de las matiere oranique. Terre et Vie 29: 203-228.

Iverson, L.R., S. Brown, A. Prasad, H. Mitasova, A.J.R. Gillespie, and A.E. Lugo. 1994. Use of GIS for estimating potential and actual forest biomass for continental South and Southeast Asia, pp. 67-115. In Effects of Land- Use Change on Atmospheric $\mathrm{CO}_{2}$ Concentrations: South and Southeast Asia as a Case Study, V.H. Dale (ed.). Springer-Verlag Inc., New York.

Jaakkola, S. 1990. Managing data for the monitoring of tropical forest cover: The Global Resources Information Database approach. Photogrammetric Engineering and Remote Sensing 56: 1355-1358.

Lamotte, M. 1975. The structure and function of a tropical savanna ecosystem, pp. 179-222. In Tropical Ecosystems: Trends in Terrestrial and Aquatic Research, F.B. Golley and E. Medina (eds). Springer-Verlag Inc., New York.

Lamotte, M. and F. Bourliere. 1983. Energy flow and nutrient cycling in tropical savannas, pp. 583-603. In Ecosystems of the World 13:Tropical Savannas, F. Bourliere (ed.). Elsevier, Amsterdam, The Netherlands.

Lavenu, F. 1987. Vegetation Map of Africa 1:5,000,000. Institue de la Carte Internationale de la Vegetation, Universitie Paul Sabatier, Toulouse, France. Distributed by FAO Forest Resources Assessment Project-1990, Rome, Italy.

Martin, C. 1991. The Rainforests of West Africa. Birkhauser Verlag, Basel, Switzerland.

Menaut, J.C., L. Abbadie, F. Lavenu, P. Loudjami, and A. Podaire. 1991. Biomass burning in west African Savannas, pp. 133-142. In Global Biomass Burning: Atmospheric, Climatic and Biospheric Implications, J.S. Levine (ed). MIT Press, Cambridge, Massachusetts.

Olson, J.S., J.A. Watts, and L.J. Allison. 1983. Carbon in Live Vegetation of Major World Ecosystems. TR004, U.S. Department of Energy, Office of Energy Research, Washington, D.C.

Olson, J.S., R.M. Garrles, R.A. Berner, T.V. Armentano, M.I. Dyer, and D.H. Yaalon. 1985. The natural carbon cycle, pp. 175-214. In Atmospheric Carbon Dioxide and the Global Carbon Cycle, J.R. Trabalka (ed.). DOE/ER0239. U.S. Department of Energy, Office of Energy Research, Washington, D.C.

Pierlot, R. 1966. Structure et composition de forets denses d'Afrique, especialement celles du Kivu. Academie Royale des Sciences d'Outre-mer, Classes des Sciences naturelles et Medicales N.S.-XVI-4, Bruxelles, Belgium.

Rand McNally Co. 1980. The new International Atlas. Rand McNally, Chicago, Illinois.

Republique de Cote d'Ivoire. 1975. Analyse et Commentaires des Resultats de l'Inventaire Forestier de la Region Nord-Ouest: Resultats de la Region du Nord-Ouest. Inventaire Forestier National, Direction des Inventaire et Amenagement, Abidjan, Ivory Coast.

Smith, K.R. 1991. Biomass cook stoves in global perspectives: Energy, health, and global warming. In The Earth as System Central. EWC/ESMAP/UNDP Report 3, The World Bank, Washington, D.C. 
Udo, R.K. 1982. The Human Geography of Tropical Africa. Heinemann Educational Books, London, United Kingdom.

United Nations. 1972. Forestry Inventory of the Gola Forest Reserves: Report to the Government of Sierra Leone. FAO, Rome, Italy.

UNESCO/AETFAT/UNSO. 1981. Vegetation Map of Africa 1:5,000,000. Oxford University Press, Hammond and Kell Ltd., Mitcham, Surrey, United Kingdom.

Weck, J. 1970. An improved CVP-index for the delimitation of the potential productivity zones of forest lands of India. Indian Forester 96: 565-572.

White, F. 1983. The vegetation of Africa: A descriptive memoir to accompany the Unesco/AETFAT/UNSO vegetation map of Africa. UNESCO, United Nations, New York.

Worldmark Press, Ltd. 1984. Encyclopedia of the Nations, vol. 2 (Africa). John Wiley and Sons Inc., New York.

\section{HOW TO OBTAIN THE DATA AND DOCUMENTATION}

These data may be used with a vector or raster geographic information system (GIS) or non-GIS database systems. This database (NDP-055) is available free of charge from CDIAC. The files are available, via the Internet, from CDIAC's World-Wide-Web site (http://cdiac.esd.ornl.gov), or from CDIAC's anonymous file transfer protocol (FTP) area (cdiac.esd.ornl.gov) as follows:

1. FTP to cdiac.esd.ornl.gov (128.219.24.36).

2. Enter "ftp" as the user id.

3. Enter your electronic mail address as the password (e.g., fred@zulu.org).

4. Change to the directory "pub/ndp055" (i.e., use the command "cd pub/ndp055").

5. Set ftp to get ASCII files by using the ftp "ascii" command.

6. Retrieve the ASCII database documentation file by using the ftp "get ndp055.txt" command.

7. Retrieve the ASCII data files by using the ftp "mget *.asc" command.

8. Retrieve the ASCII FORTRAN files by using the ftp "mget *.for" command.

9. Retrieve the ASCII SAS ${ }^{\mathrm{TM}}$ files by using the ftp "mget *.sas" command.

10. Set ftp to get BINARY files by using the ftp "binary" command.

11. Retrieve the binary ARC/INFO ${ }^{\mathrm{TM}}$ export files by using the ftp "mget *.e00" command.

12. Exit the system by using the ftp "quit" command.

For non-Internet data acquisitions (e.g., floppy diskette or CD-ROM) or ifor additional information, contact:

Carbon Dioxide Information Analysis Center

Oak Ridge National Laboratory

P.O. Box 2008

Oak Ridge, Tennessee 37831-6335, U.S.A.

Telephone: 1-865-574-3645

Telefax: 1-865-574-2232

E-mail: cdiac@ornl.gov

\section{LISTING OF FILES PROVIDED}


This database consists of 36 files: two *.txt files, seven *.e00 GIS data files, one *prj projection file, seven *.asc data files, four FORTRAN input statement files, and four SAS input statement files, and $13 *$.gif graphics files. See Table 1 for a complete listing and description of these files.

\section{DESCRIPTION OF THE DOCUMENTATION FILE}

The ndp055.txt (File 1) file is an ASCII text equivalent of this document.

\section{DESCRIPTION, FORMAT, AND PARTIAL LISTINGS OF THE DATA FILES}

Table 1 lists and describes the files included in this numeric data package.

\section{FLAT ASCII DATA FILES:}

Eight flat ASCII data files are provided with this data package. These files contain the same information as the ARC INFO grids and coverages included in this NDP. The ASCII files were either created directly from the ARC/INFO grids of the same name using the GRIDASCII command or are ASCII versions of ARC/INFO attribute tables associated with polygon coverages included in this NDP. SAS and FORTRAN programs designed to read and print the contents of each ASCII data file are also provided. The information within these files will allow the user to ascertain population densities, the amount of land remaining in forests in 1980, the maximum potential aboveground biomass densities within Africa, and the biomass in aboveground woody vegetation in Tropical Africa in 1980. What follows is a description of the contents and formats (e.g., variable names, widths) of the eight flat ASCII data files distributed with this data package.

The flat ASCII files BIOMAX.ASC (File 4), LAKES.ASC (File 6), and LAND.ASC (File 8) are formatted as shown in the following FORTRAN code and may be read using the input/output programs INTGRID.FOR (File 9) or INTGRID.SAS (iㅣ 10).

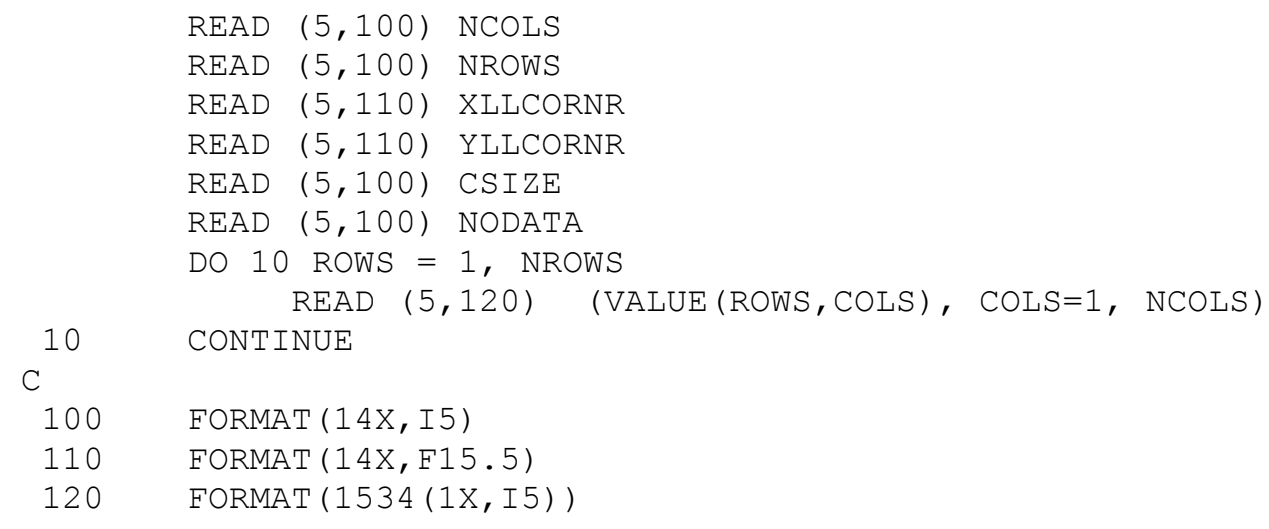

BIOMAX.ASC contains maximum potential biomass density data in $\mathrm{Mg} / \mathrm{ha}$; LAND.ASC contains land-use information classified into four land-use categories; and LAKES.ASC contains the location of all non-seasonal lakes $>20 \mathrm{~km}$ in any direction in Tropical Africa. Each file of these three files contains header information containing a set of key words followed by cell (i.e., data) values in row-major order. The first six lines of BIOMAX.ASC, LAKES.ASC, and LAND.ASC (header information) are:

ncols 1534

nrows 1502 


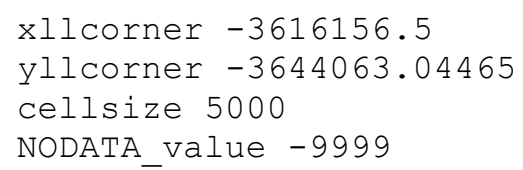

The data are in a normal (type 1) cylindrical equal-area projection with a central meridian of 15 degrees East longitude and a standard parallel of 0 degrees latitude. Data are provided for 1,502 rows and 1,534 columns, with the first cell being located in the upper-left corner. Each data cell covers a $25 \mathrm{~km}^{2}$ square area, $5,000 \mathrm{~m}$ per side. The area covered by the data is bounded by a box with the following coordinates: lower-left -3616156.500 , 3644063.04465; upper-right 4053843.500, 3865936.955.

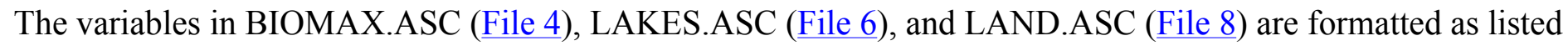
in Table 4 and are shown in the same order as they would appear in the files.

The flat ASCII files PD80.ASC (File 14) and BIO1980.ASC (File 12) are formatted as shown in the following FORTRAN code and may be read using the input/output programs REALGRID.FOR (File 15) or REALGRID.SAS (ile 16).

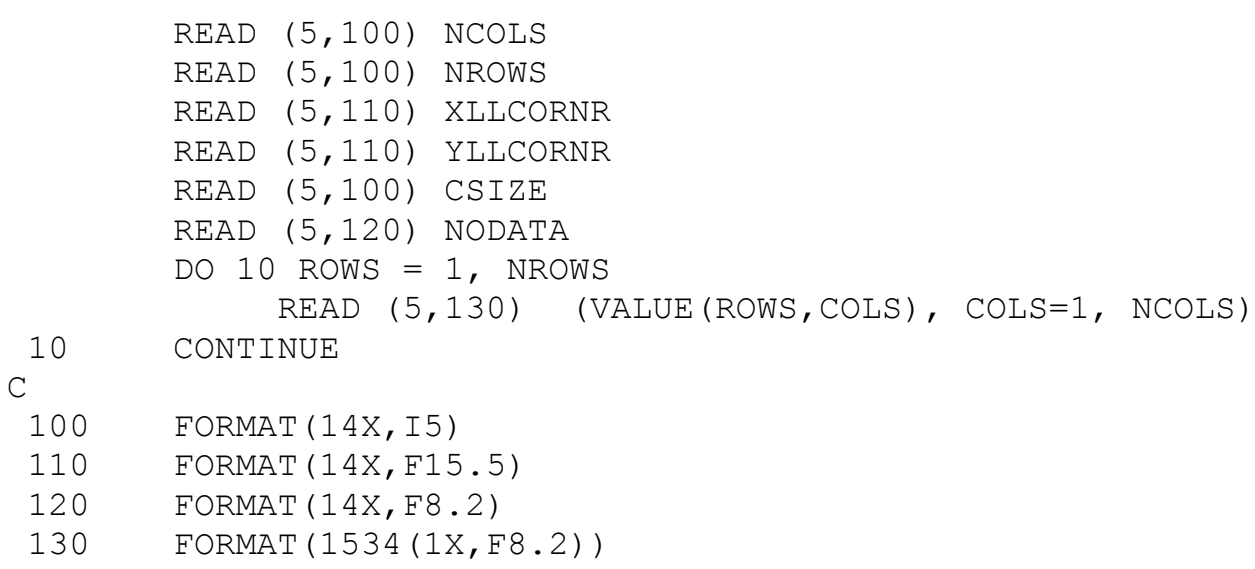

PD80.ASC contains population-density data for 1980 in people $/ \mathrm{km}^{2}$ and BIO1980.ASC contains the calculated "actual" aboveground live biomass in open and closed forest for 1980 in $\mathrm{Mg} / \mathrm{ha}$. Each of these two files contains header information with a set of key words followed by cell values in row-major order.

The first six lines of PD80.ASC, and BIO1980.ASC (header information) are :

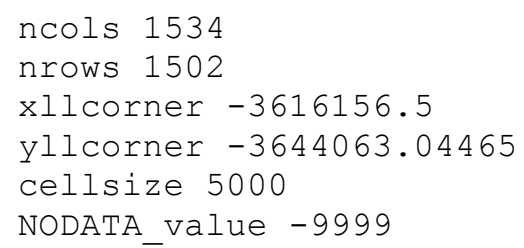

The data are in a normal (type 1) cylindrical equal-area projection with a central meridian of 15 degrees East longitude and a standard parallel of 0 degrees latitude. Data are provided for 1,502 rows and 1,534 columns with the first cell located in the upper-left corner. Each data cell covers a square area, 5,000 m per side. The area covered by the data is bounded by a box with the following coordinates: lower-left -3616156.500 , 3644063.04465; upper-right 4053843.500, 3865936.955. 
The variables in PD80.ASC (File 14) and BIO1980.ASC (File 12) are formatted as listed in Table 5 and are shown in the same order as they would appear in the files.

The flat ASCII file T_AFR.ASC (File 22) contains population density data for 1960, 1970, 1980, and 1990 for the subnational political units used in this database. The data were provided by M. Lorenzini and K. D. Singh (FAO, Tropical Forest Resources Assessment Program 1990). The file is formatted as shown in the following FORTRAN code and may be read using the input/output programs T_AFR.FOR (File 23) or T_AFR.SAS (File 24).

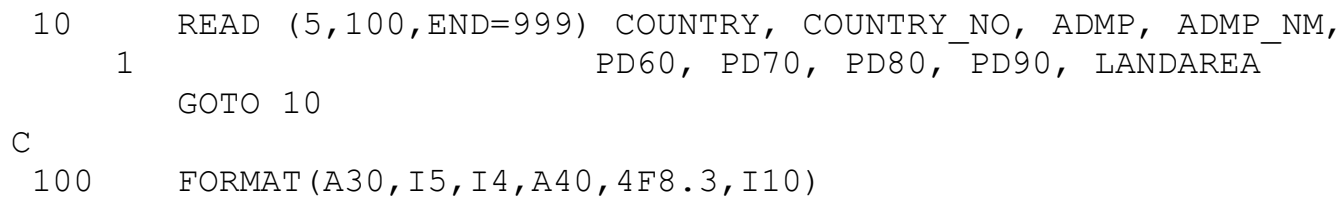

The variables in T_AFR.ASC (File 22) are formatted as listed in Table 6 and are shown in the same order as they appear in the file.

The first ten data records of $t$ _afr.asc are:

\begin{tabular}{|c|c|c|c|c|c|c|c|c|}
\hline Water & 0 & 0 & & 0 & 0 & 0 & 0 & 0 \\
\hline Mauritania & 136 & 287 & TIRIS_ZEMOUR & 0.058 & 0.077 & 0.106 & 0.148 & 252900 \\
\hline Mali & 133 & 275 & TOMBŌ̄CTOU & -1 & -1 & 1.215 & 1.236 & 408977 \\
\hline Water & 0 & 0 & & 0 & 0 & 0 & 0 & 0 \\
\hline Niger & 158 & 306 & AGADEZ & -1 & 0.111 & 0.196 & 0.334 & 714790 \\
\hline Chad & 39 & 74 & $\mathrm{BET}$ & 0.119 & 0.138 & 0.147 & 0.17 & 600350 \\
\hline Mauritania & 136 & 283 & ADRAR & 0.326 & 0.301 & 0.253 & 0.161 & 215300 \\
\hline Mauritania & 136 & 278 & HODH_CHARKI & 0.986 & 0.953 & 0.877 & 0.71 & 182700 \\
\hline Sudan & 206 & 387 & NORTE__REGION & -1 & 1.942 & 2.176 & 2.339 & 477405 \\
\hline Sudan & 206 & 388 & EAST_REGION & -1 & 4.28 & 5.952 & 8.273 & 334331 \\
\hline
\end{tabular}

The last ten data records of $\mathrm{t} \_$afr.asc are:

$\begin{array}{lrrlrrrrr}\text { Mozambique } & 144 & 296 & \text { INHAMBANE } & 9.594 & 12.542 & 14.517 & 17.591 & 68615 \\ \text { Botswana } & 20 & 18 & \text { KGALAGADI } & 0.142 & 0.157 & 0.217 & 0.286 & 106940 \\ \text { Botswana } & 20 & 20 & \text { KWENENG } & 1.9 & 2.027 & 3.096 & 4.419 & 35890 \\ \text { Botswana } & 20 & 19 & \text { KGATLENG } & 3.57 & 4.295 & 5.445 & 6.757 & 7960 \\ \text { Botswana } & 20 & 23 & \text { NGWAKETSE } & 2.246 & 2.812 & 3.863 & 5.237 & 27370 \\ \text { Mozambique } & 144 & 298 & \text { CID_MAPUTO_MAPUTO_PROV } & 18.545 & 34.664 & 47.177 & 69.288 & 26358 \\ \text { Botswana } & 20 & 24 & \text { BAROLONG_SOUTH_EAST } & 10.397 & 21.905 & 40.573 & 71.489 & 2880 \\ \text { Mozambique } & 144 & 298 & \text { CID_MAPUTO_MAPUTO_PROV } & 18.545 & 34.664 & 47.177 & 69.288 & 26358 \\ \text { Zimbabwe } & 181 & 337 & \text { MATABBELLAND_NORTE } & -1 & 8.159 & 11.329 & 15.806 & 73537 \\ \text { Zimbabwe } & 181 & 339 & \text { MIDLANDS } & -1 & 13.191 & 17.577 & 23.54 & 58967\end{array}$

The flat ASCII file AFRICA.ASC (File 19) contains the amount of land and biomass in open and closed forest by country for 1980. The file is formatted as shown in the following FORTRAN code and may be read by using the input/output programs AFRICA.FOR (ile 20) or AFRICA.SAS (File 21).

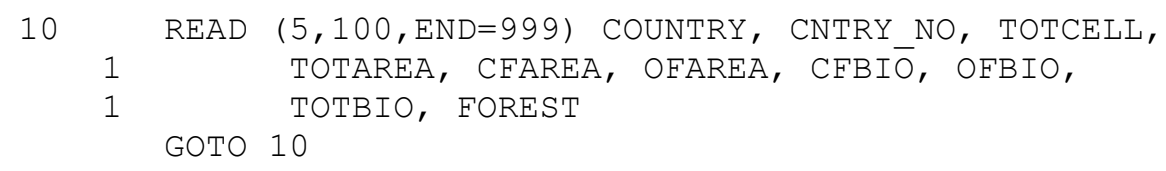


C

100 FORMAT (A30,I5,I11,I10,2I9,2F12.1,F12.4,F12.1)

The variables in AFRICA.ASC (ile 19) are formatted as listed in Table 7 and are shown in the same order as they appear in the file.

The first ten data records of africa.asc are:

$\begin{array}{lrrrrrrrrr}\text { Angola } & 7 & 50127 & 1253175 & 66750 & 1063775 & 109.4 & 69.7 & 8144.76 & 90.2 \\ \text { Botswana } & 20 & 23195 & 579875 & 0 & 101800 & 0 & 13.1 & 133.36 & 17.6 \\ \text { Burundi } & 29 & 1021 & 25525 & 2575 & 6900 & 57.1 & 40.3 & 42.51 & 37.1 \\ \text { Cameroon } & 32 & 18529 & 463225 & 221750 & 182500 & 297.5 & 120 & 8787.06 & 87.3 \\ \text { Central African Republic } & 37 & 24856 & 621400 & 105425 & 515850 & 262.9 & 185.7 & 12350.96 & 100 \\ \text { Chad } & 39 & 50635 & 1265875 & 0 & 316825 & 0 & 38 & 1203.94 & 25 \\ \text { Congo } & 46 & 13841 & 346025 & 247675 & 375 & 344.9 & 36.4 & 8543.68 & 71.7 \\ \text { Benin } & 53 & 4664 & 116600 & 4325 & 103675 & 75.6 & 56.4 & 617.42 & 92.6 \\ \text { Equatorial Guinea } & 61 & 1072 & 26800 & 24725 & 0 & 318 & 0 & 786.26 & 92.3 \\ \text { Ethiopia } & 62 & 49920 & 1248000 & 375450 & 325400 & 65.3 & 35.6 & 3610.11 & 56.2\end{array}$

The last ten data records of africa.asc are:

$\begin{array}{lrrrrrrrrr}\text { Senegal } & 195 & 7916 & 197900 & 13500 & 63975 & 52.8 & 25.8 & 236.34 & 39.1 \\ \text { Sierra Leone } & 197 & 2899 & 72475 & 30875 & 28400 & 220.6 & 174.9 & 1177.82 & 81.8 \\ \text { Somalia } & 201 & 25573 & 639325 & 350 & 165675 & 11.4 & 12.4 & 205.84 & 26 \\ \text { Sudan } & 206 & 99743 & 2493575 & 5425 & 737150 & 134 & 63 & 4716.74 & 29.8 \\ \text { Tanzania } & 215 & 35629 & 890725 & 5550 & 529800 & 73.5 & 48.6 & 2615.62 & 60.1 \\ \text { Togo } & 217 & 2297 & 57425 & 725 & 49575 & 40.9 & 71.7 & 358.42 & 87.6 \\ \text { Uganda } & 226 & 8204 & 205100 & 12075 & 131825 & 124 & 101.7 & 1490.39 & 70.2 \\ \text { Burkina Faso } & 233 & 10957 & 273925 & 0 & 97375 & 0 & 34 & 331.08 & 35.5 \\ \text { Zaire } & 250 & 92433 & 2310825 & 1860300 & 378175 & 223.9 & 118.2 & 46122.15 & 96.9 \\ \text { Zambia } & 251 & 29846 & 746150 & 47250 & 579650 & 45.9 & 52.3 & 3248.45 & 84\end{array}$

\section{ARC/INFO (Version 7.2.1) EXPORT FILES}

Seven ARC/INFO export files (*.e00) are provided with this NDP. These files contain the same data as the flat ASCII data files described previously. The ARC/INFO export (*.e00) files were produced using the EXPORT command with the NONE option in ARC/INFO Version 7.2.1. These files are in an uncompressed, fixed-block format that may be moved across computer systems. The coverages are in a normal (type 1) cylindrical equalarea projection with a central meridian of 15 degrees East longitude and a standard parallel of 0 degrees latitude. All units are in meters and the spheroid is a sphere with a radius of 6,370,997 meters (vs. the Clark 1866 spheroid).

The following files (BIOMAX.E00, LAND.E00, PD80.E00, LAKES.E00 and BIO1980.E00) should be imported with the GRID option and contain 1,502 rows and 1,534 columns, with each data cell covering a square area with $5,000 \mathrm{~m}$ per side. The remaining files (T_AFR.E00 and AFRICA.E00) are ARC/INFO polygon coverages and should be imported using the COVER option. The polygon coverage AFRICA contains regions. The region subclass within AFRICA is named SUM1980. These regions were built using countries within Tropical Africa as unique identifiers. The AFRICA.PAT.SUM1980 INFO file contains summary information by country for the amount of land and biomass in open and closed forests in 1980. The area covered by the data is bounded by a box with the following coordinates: lower-left -3616156.500, -3644063.04465; upper-right 4053843.500, 
3865936.955. A listing of the variable names and data formats for these last two export (E00) files are shown in Tables $\underline{6}$, and $\underline{7}$.

The first ten data records of BIOMAX.E00 are:

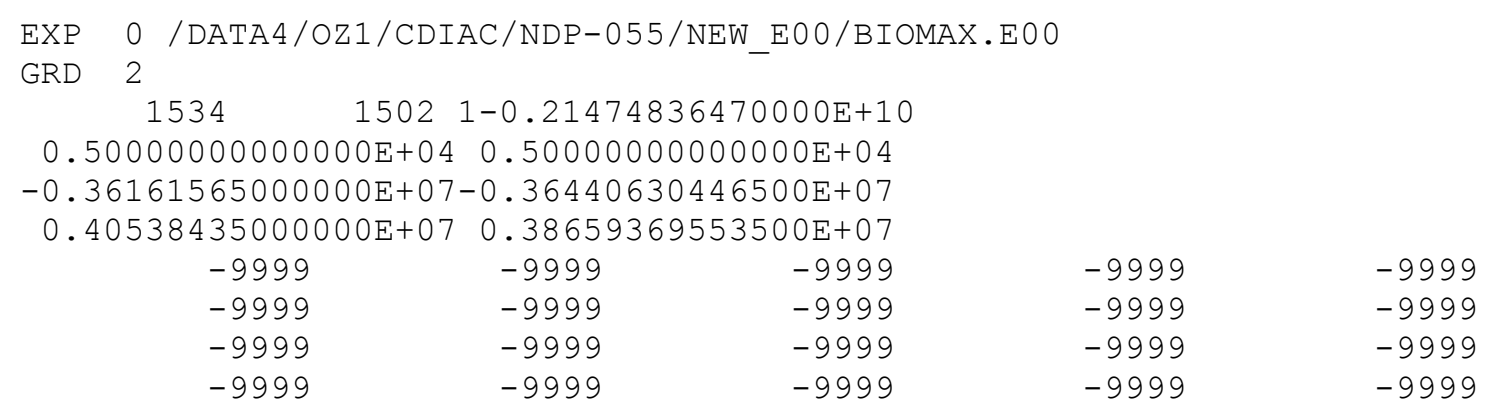

The last ten data records of BIOMAX.E00 are:

$\begin{array}{rr}42 & 90055 \\ 75 & 91074 \\ 150 & 99339 \\ 250 & 81883 \\ 350 & 64032 \\ 425 & 37550 \\ 475 & 17970 \\ 500 & 2264\end{array}$

EOI

EOS

The first ten data records of LAND.E00 are:

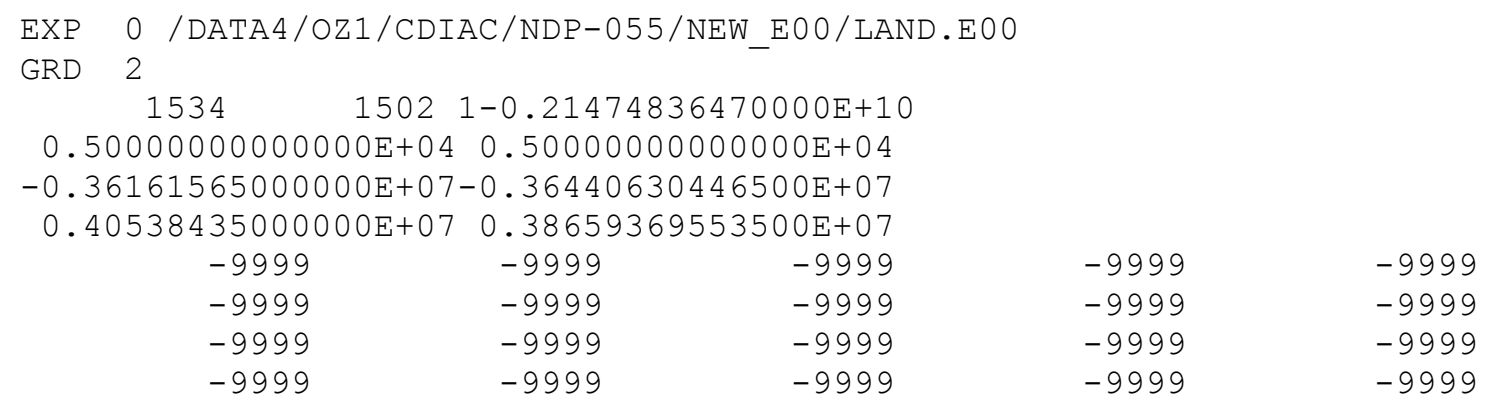

The last ten data records of LAND.E00 are:

\begin{tabular}{|c|c|c|c|c|c|c|c|}
\hline LAND. VAT & & & $x X$ & 2 & 2 & 8 & 5 \\
\hline VALUE & $4-1$ & $14-1$ & $10-1$ & $50-1$ & -1 & $-1-1$ & \\
\hline COUNT & $4-1$ & $54-1$ & $10-1$ & $50-1$ & -1 & $-1-1$ & \\
\hline-9999 & 1105588 & & & & & & \\
\hline 1 & 175811 & & & & & & \\
\hline 2 & 346001 & & & & & & \\
\hline 3 & 157539 & & & & & & \\
\hline
\end{tabular}


EOI

$4 \quad 519129$

EOS

The first ten data records of PD80.E00 are:

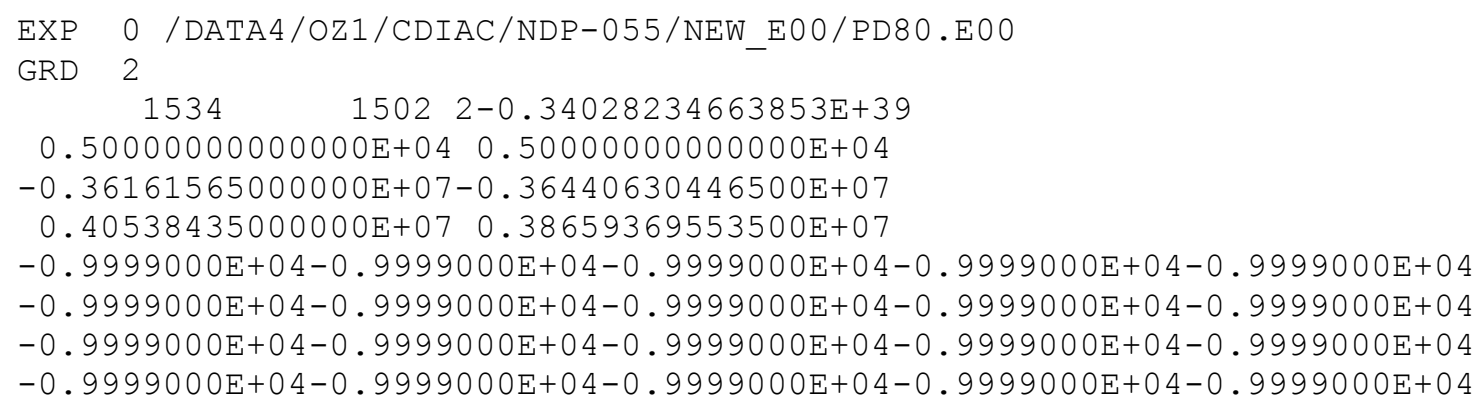

The last ten data records of PD80.E00 are:

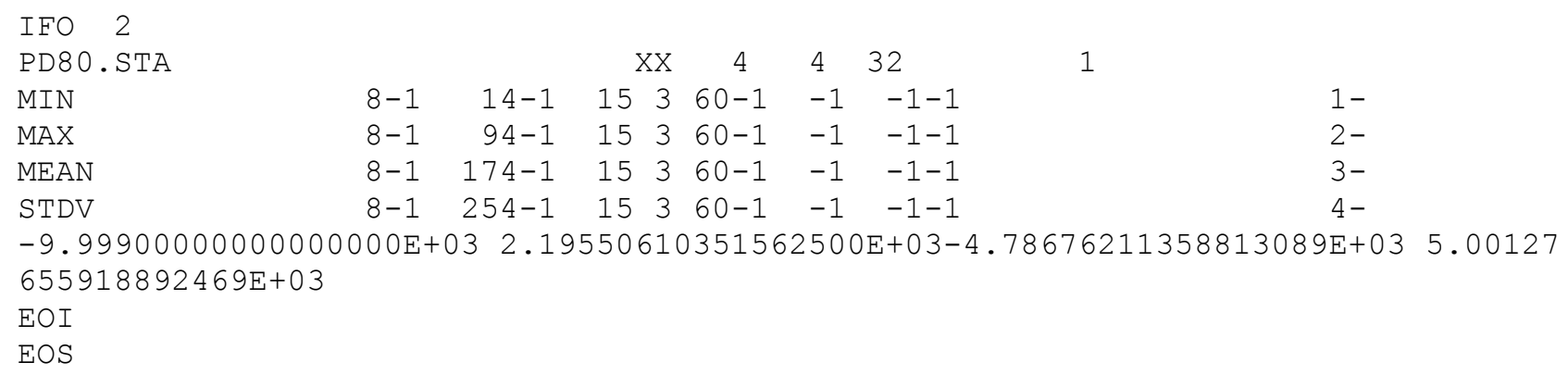

The first ten data records of LAKES.E00 are:

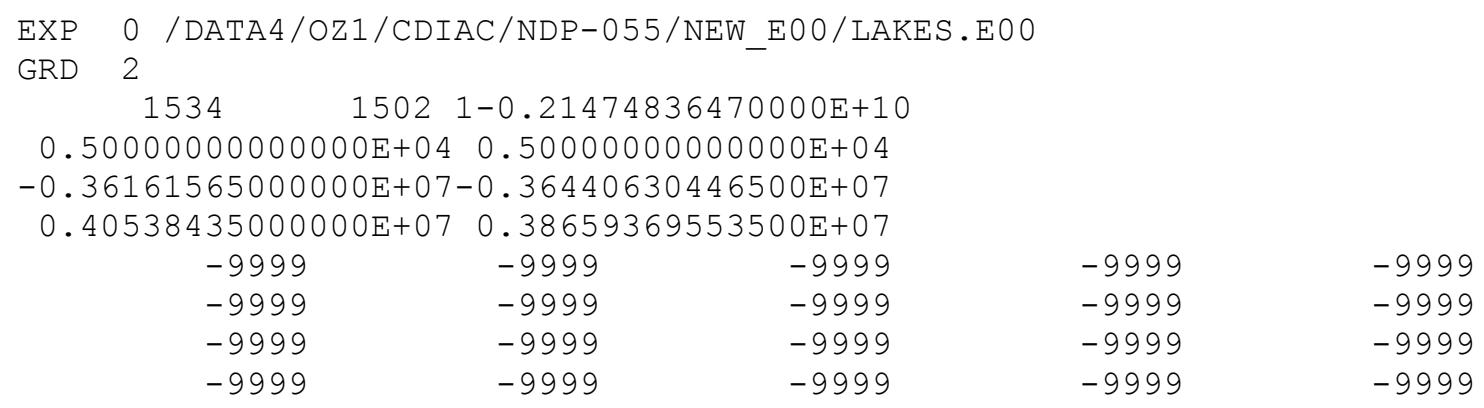

The last ten data records of LAKES.E00 are:

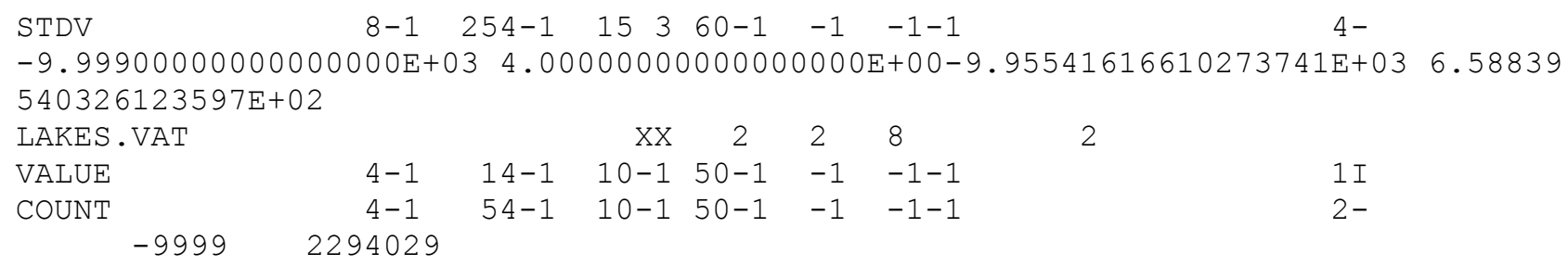




$\begin{array}{ll}\text { EOI } & 4 \\ \text { EOS } & \end{array}$

The first ten data records of BIO1980.E00 are:

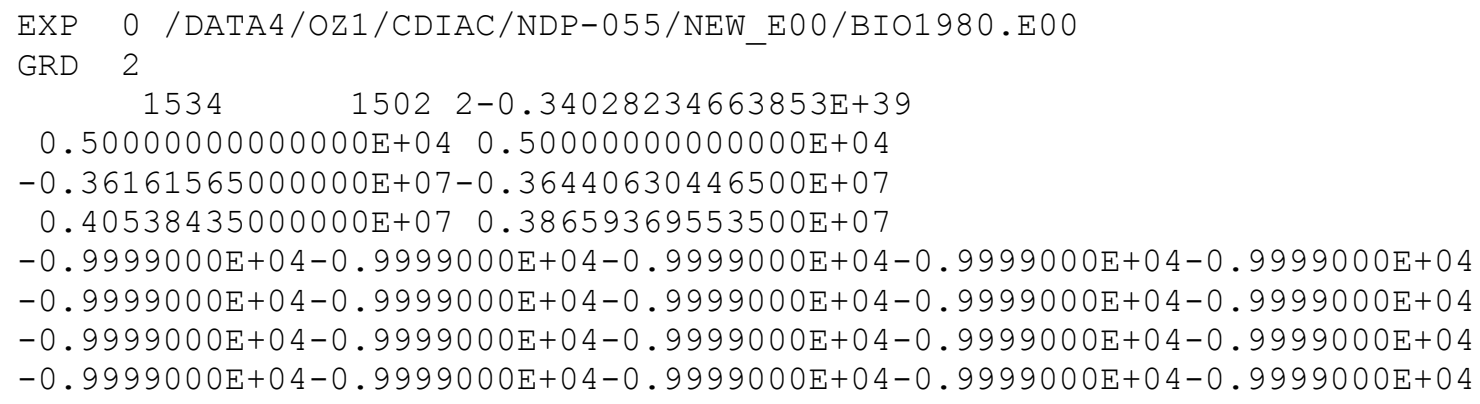

The last ten data records of BIO1980.E00 are:

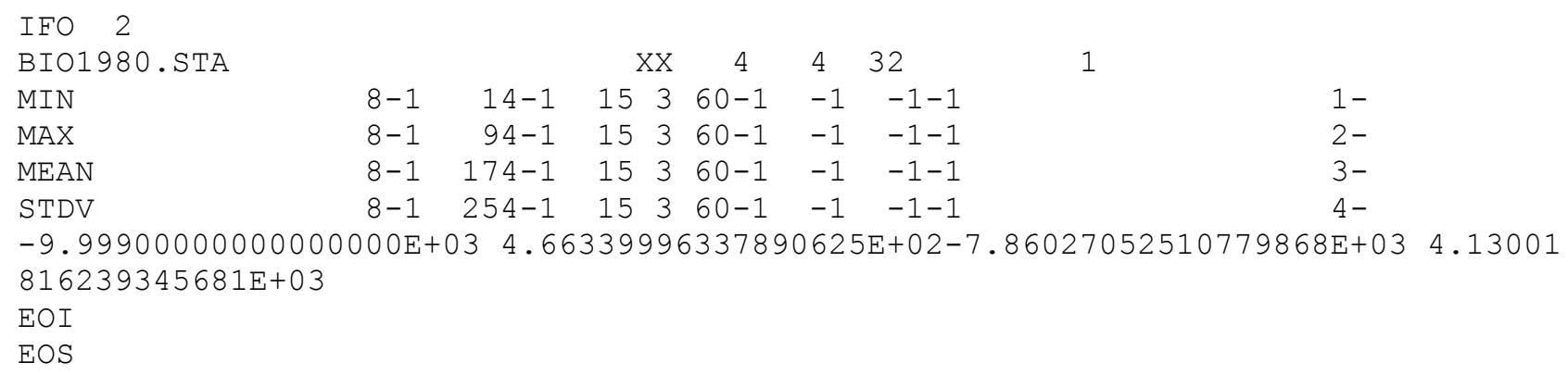

\section{SAS AND FORTRAN CODES TO ACCESS THE DATA}

BIOMAX.ASC (File 4), LAKES.ASC (File 6), and LAND.ASC (File 8) may be read using the input/output programs INTGRID.FOR (ile 9) or INTGRID.SAS (ile 10).

\section{INTGRID.FOR (File 9):}

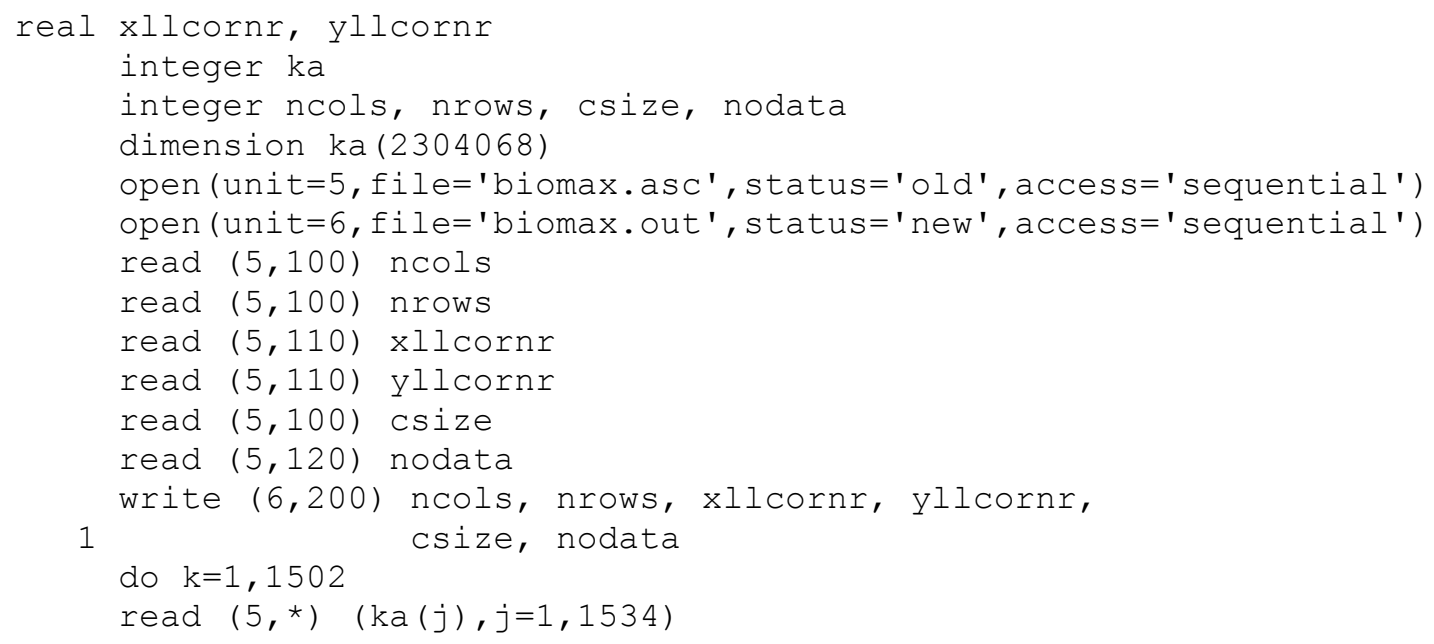




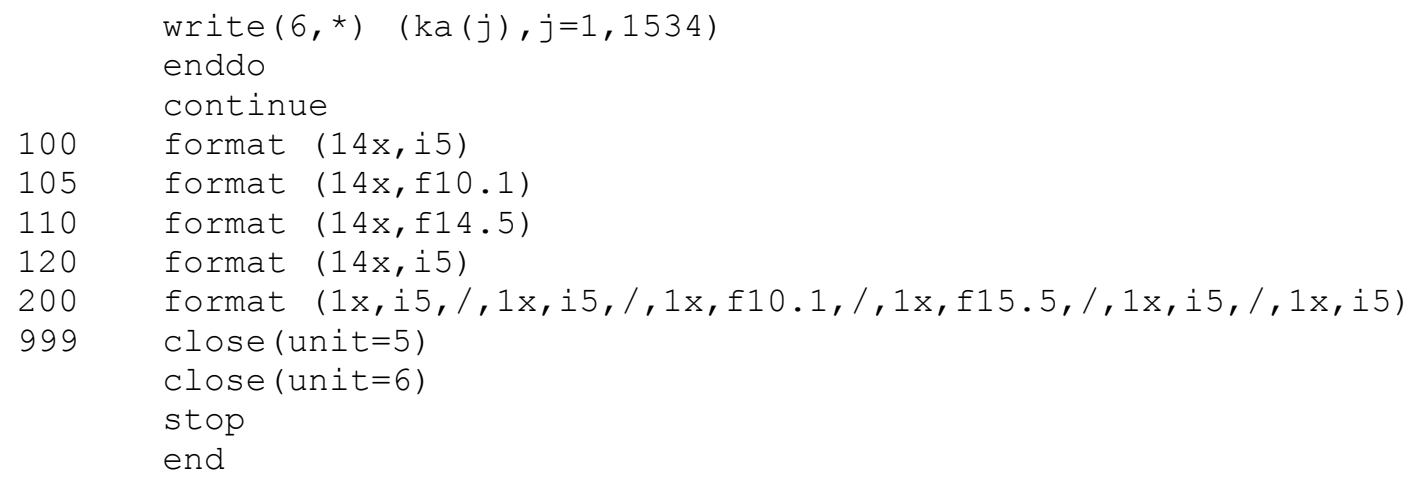

INTGRID.SAS (File 10):

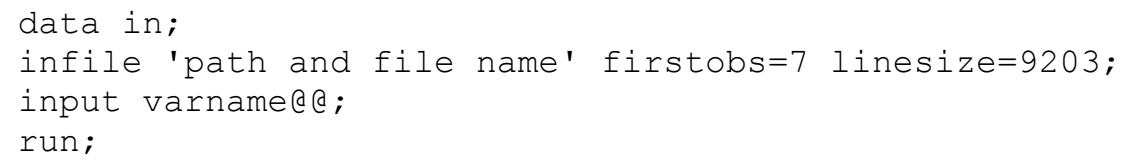

The flat ASCII files PD80.ASC (File 14) and BIO1980.ASC (File 12) may be read using the input/output programs REALGRID.FOR (File 15) or REALGRID.SAS (File 16).

\section{REALGRID.FOR (File 15):}

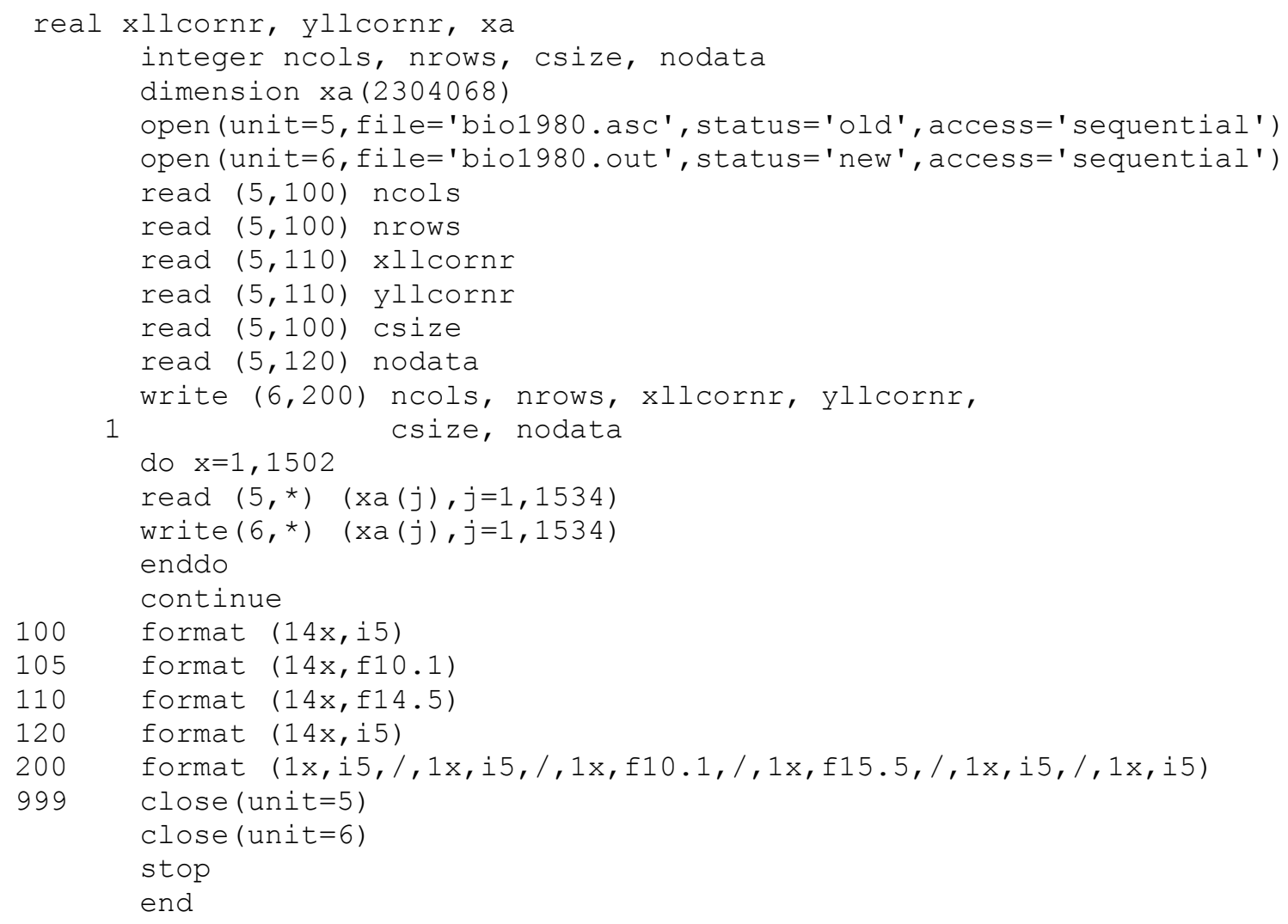




\section{REALGRID.SAS (File 16):}

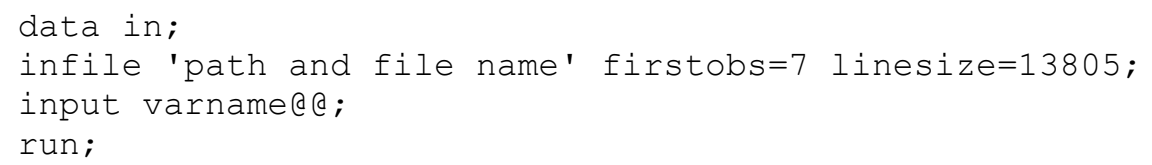

The flat ASCII file T_AFR.ASC (File 22) may be read using the input/output programs T_AFR.FOR (ile 23) or T_AFR.SAS (File 24).

\section{T_AFR.FOR (File 23):}

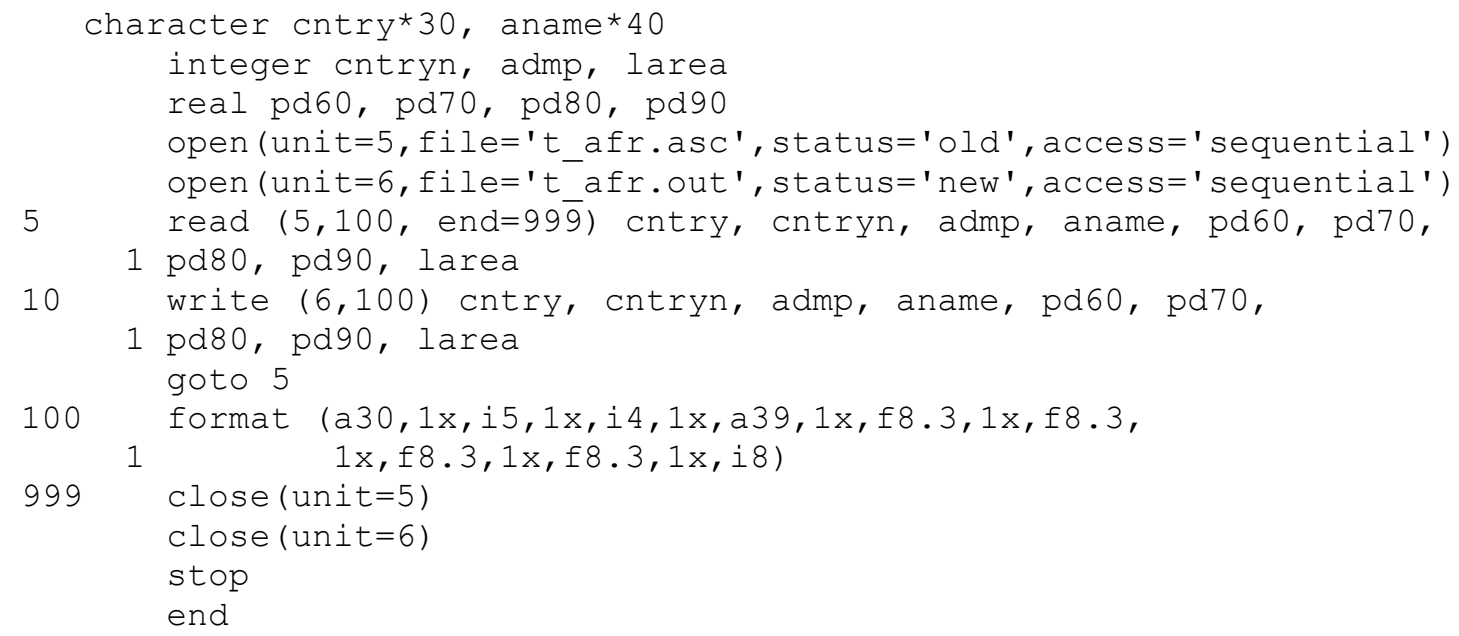

T_AFR.SAS (File 24):

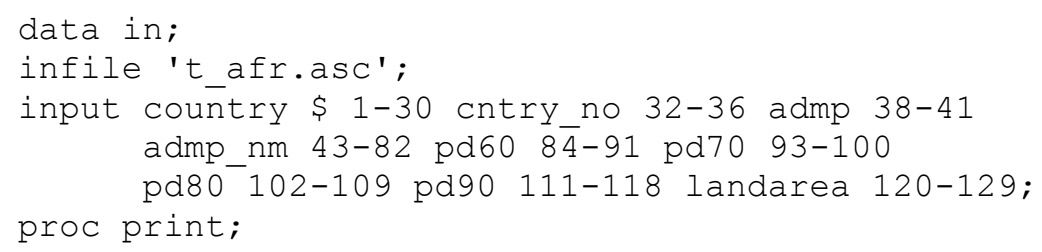

The flat ASCII file AFRICA.ASC (File 19) may be read by using the input/output programs AFRICA.FOR (File 20) or AFRICA.SAS (File 21).

AFRICA.FOR (File 20):

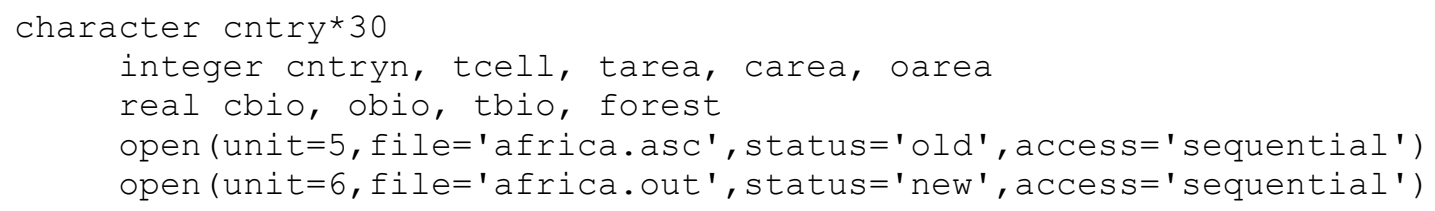




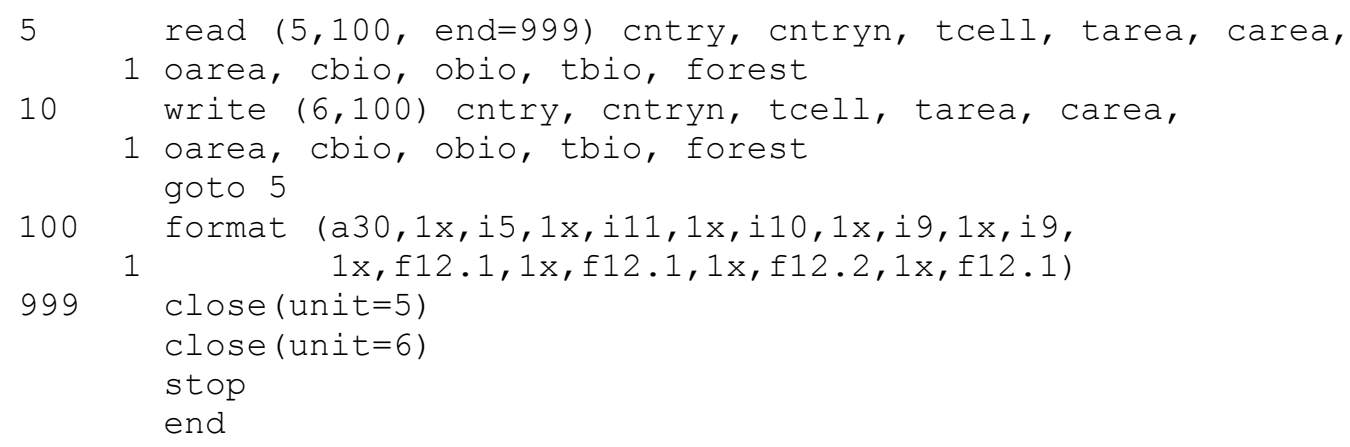

\section{AFRICA.SAS (File 21):}

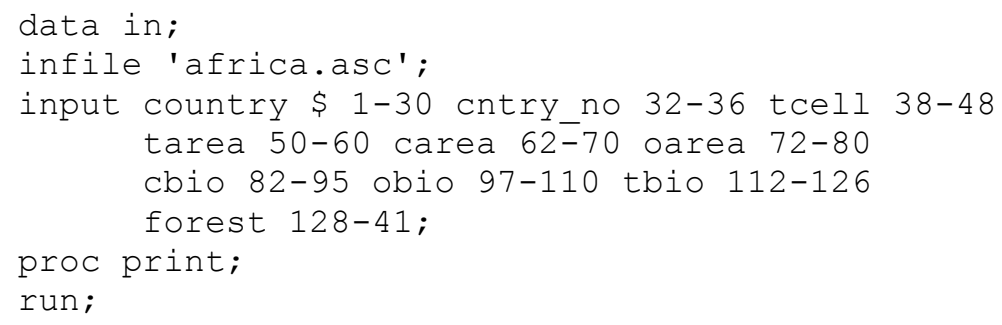

